\title{
Humanitarian Aid and Health Services in Eastern Kivu, Zaïre: Collaboration or Competition?
}

\author{
PHILIPPE GOYENS 1.2 \\ DENIS PORIGNON' \\ ETIENNE MUGISHO SORON'GANE 1.3 \\ RENE TONGLET 1,4 \\ PHILIPPE HENNART 1 \\ HENRI LOUIS VIS ${ }^{2}$
}

1. Centre for Scientific and Medical Research of the Free University of Brussels for its Overseas Cooperation Activities (CEMUBAC)

2 Paediatric Laboratory, Free University of Brussels

3. Health Districts of Kirotshe Rutshuru and Masisi Ministry of Health of the Republic of Zaire 4. Epidemiology Unit, Cathalic University of Lowain

The population of eastern Kivu, like that of Rwanda, has been surviving in critical conditions for many years. The Rwandan refugees of 1994 fled into an area with its own serious problems. The Zairean health services in the health districts of Rutshuru, Kirotshe and Masisi, in spite of the political and socioeconomic disintegration of the country, were still functioning, and the local hospitals and health centres, although overwhelmed, contributed to a large extent to the disaster response. Prominent among the major problems facing the local health services were their limited adaptability, the inadequate coordination and collaboration offered to them by the humanitarian aid agencies, and the discrimination between the direct and secondary victims of the emergency. The public health consequences of the Rwandan refugee crisis for the Zairean population constitute an integral part of the disaster.

Did the humanitarian aid agencies and the local health services in eastern Kivu collaborate, or rather compete, in response to the Rwandan emergency? To answer this question, this paper focuses on the zones de santé of Kirotshe, Rutshuru and Masisi, where most Rwandan refugees in eastern Kivu are concentrated, and also where the medical team of CEMUBAC is active.

\section{Eastem Kivu and its Population}

Lake Kivu, on the border between Zaïre and Rwanda, is surrounded by highlands with a mean altitude of 1700 metres. The climate is temperate. The 
year is divided into the dry season from June to October, and the rainy season, which is interrupted by a very short dry season-two or three weeks-at the end of January (Vis et al. 1969).

\section{Population}

The indigenous population in eastern Kivu, on the western shore of the lake, comprises lactose intolerant Shi, Havu, Hunde and Nande tribes; their main occupation is subsistence farming (Vis et al. 1969).

Emigration from Rwanda to Zaīre is a very old phenomenon, the consequence of recurrent episodes of famine in Rwanda. It was organized by the Belgian colonial authority, mainly towards Masisi district, where 170,000 $R$ wandans were recorded in 1955 . They were estimated to be 335,000 in eastern Kivu in 1970. As a consequence, Masisi district, in 1993, was believed to have 650,000 inhabitants, including 400,000 of Rwandan origin, mainly Hutus. In 1993, before the recent influx of refugees, the Hutus were certainly the most important ethnic group in the health districts of Masisi and Rutshuru-up to 80 per cent of the population in certain areas. Five per cent of the population were Tutsi-Himas. These traditional lactose tolerant cattle breeders originally lived in Rwanda, and first emigrated to Kivu because of overpopulation in Rwanda, but on subsequent occasions, in 1959, 1964, and 1973, for political reasons. Since the recent influx of refugees, the Tutsi-Himas have been moving back to Rwanda to escape being murdered by the defeated Hutu extremists.

For some years now ethnic conflicts have also put the Rwandan immigrants in opposition to the native Zairrean populations, Hunde and Nande, who represent no more than one third of the total population of the Masisi district. The arrival of $700,000-800,000$ supplementary Hutus poses a serious problem for that part of Zaire.

Population density in Kivu is also high, although lower than in Rwanda. The population doubles every 20 to 22 years (Vis 1975; Wils et al. 1986). The population of the Masisi district, for instance, was estimated to be 650,000 , or more than 160 inhabitants per square kilometre. Kabare, a rural area northwest of Bukavu, has now more than 200 inhabitants per square kilometre.

\section{Food Consumption and Health Status}

The rural population lives in a near-subsistence economy (farming or informal commercial activity) (Jones and Egli 1984) and energy consumption is chronically insufficient (Vis et al. 1969), varying according to the population density. Protein intake is likewise marginal in the whole area (Vis et al. 1969). Significant seasonal variations of protein intake occur, mainly in those areas where 50 per cent of the protein ingested comes from beans. Protein deficiency in Kivu cannot be dissociated from energy deficiency.

The energy intake fluctuates less, because sweet potatoes and cassava are harvested throughout the year. However, overpopulation, soil exhaustion and 
soil erosion constantly reduce the arable surface (Vis 1975), and even disregarding political and economic difficulties, it can be assumed that the energy intake of the population is following a downward trend (Wils et al. 1986).

There is evidence that protein and energy deficiencies in Kivu are accompanied by deficiencies of various micronutrients: vitamins (e.g. riboflavin, nicotinic acid, alpha-tocopherol, vitamin A) as well as minerals (e.g. iodine and selenium) (Delange 1974; Goyens et al. 1987).

As in most tropical environments, parasitic infestation is massive, occurring very early in life. More than 90 per cent of the children above two years of age excrete parasites (IRS-CEMUBAC 1979). Malaria-Plasmodium falciparumis endemic (Delacolette et al. 1989). Incidence of bacterial infections (more particularly acute respiratory infections and diarrhoeal diseases) is extremely high. Cholera (Colaert et al. 1978) and multi-resistant shigellosis (De Mol et al. 1983; Ries et al. 1994) have been endemic since the late seventies and the early eighties.

As a consequence of these longstanding problems, relative malnutrition is the rule, characterized by intra-uterine growth retardation, early post-natal growth failure and faltering of local growth curves (IRS-CEMUBAC 1979; Tonglet et al. 1991).

Severe protein-energy malnutrition (PEM) is endemic. Marasmic kwashiorkor is the most prevalent form, the incidence increasing markedly at the end of the dry season (Vis 1968). Weaned children aged 2-4 years are the most vulnerable. However, many younger and older children, up to 10 years of age, present with clinical signs of severe PEM, as well as some adults, usually pregnant and lactating mothers.

Food availability in the cities (Bukavu and Goma) is less dependent on the seasons due to the regulatory effect of the monetary economic system. City dwellers consumed the same foods as in the rural area, with, however, a higher proportion of cassava (Vis et al. 1975). Energy and protein intakes were usually adequate. Due to the worsening of the economic and political situation, however, it may be supposed that the nutritional situation in the cities is rapidly deteriorating, so that more and more cases of PEM will appear there likewise (Tonglet et al. 1991).

The population of eastern Kivu, like the population of Rwanda (Vis 1975; Vis et al. 1975), has been enduring critical conditions for many years. The emergency did not just begin in July 1994. Indeed, clashes had already occurred in April 1993 in Masisi district, killing 5,000-10,000 people and leading to the displacement of about 165,000 . This was the expression of a longstanding latent conflict between the original population-roughly 20 per cent of the total-and Rwandan immigrants who had settled in the district since the late fifties. Native Zaïreans have political power, the $R$ wandan immigrants have the land. The 1993 conflict was due partly to the worsening conditions of life in Zaire as the economy and administrative structure were collapsing. But it was also caused by the recurrent land shortage in a subsistence economy, with 
consequent reduction of food availability and forced emigration, as foreseen by a dynamic model produced in 1978 (Wils et al. 1986). The Rwandan refugees of 1994 fled into an area with its own serious problems, where, furthermore, a large part of the population is of Rwandan origin, mostly Hutus.

\section{The Health Services in Zaire}

In the early eighties the government of Zaire chose a decentralized and integrated approach to health care provision. The Zaïrean health policy is based on a network of 306 health districts-zones de santé-whose boundaries have been defined by the pattern of use of existing health facilities rather than administrative delimitations. One health district was supposed to cater for 100,000 to 200,000 people. The health system operates at two distinct but complementary levels: the referral hospital, one per district; and several health centres, each with a catchment area of roughly 10,000 people. The network is progressively extended, ideally to cover the requirements of the entire population of the health district.

Each health entity enjoys considerable autonomy in management of daily activities, but a health district management team-the Bureau Central de Zone-comprising staff members of the health district at all levels and delegates elected by the population, headed by the district health officer, plans the programme, coordinates the activities of the health district and provides close supervision.

The hospital is staffed by a medical director and assistants, while health centres are staffed by trained nurses, assisted by auxiliary medico-social staff members. Local health committees-Comités de Santé-encourage community participation and are responsible for the maintenance of the local infrastructure-mainly buildings and furniture.

How is the system financed? In 1993, the gross national product per inhabitant was estimated to be US\$ 225 (World Bank 1993). About 0.5 per cent of this was spent in health care. Until recently, 2.5 per cent of the national budget was supposed to be devoted to public health. At the health district level, in 1989, approximately 5 per cent of expenses were covered by governmental subsidies. Clearly this is now much less, as the Zairean state is in crisis. The inhabitants have thus to rely mainly on themselves, and on external support.

\section{The Health Services in Eastern Kivu}

The North Kivu region comprises 19 health districts. Since 1985, the three health districts of Kirotshe, Masisi and Rutshuru, located close to Goma, have been implementing a comprehensive primary health care programme in collaboration with CEMUBAC and other organizations. In this programme the health centre, rather than the referral hospital, is the operational cornerstone of the system. It is supposed to answer all basic socio-medical needs in its area. It was some years before the local health committees really 
started working, but some of these are genuinely functioning as committees for integrated development now, being active in many areas besides health care. Thanks to staff motivation and the involvement of the population, the three districts seem to be making progress, in spite of the socio-economic disintegration of the country, illustrated for instance by an inflation rate of 1320 per cent between November 1993 and January 1995.

The total population of the three districts is over 700,000 people. Fifty-six to 100 per cent of the inhabitants have a health centre within $10 \mathrm{~km}$ from home. While in the Rutshuru district all health centres are operational, this is the case in only 60 per cent in Kirotshe and Masisi. Fifteen to 30 per cent of the population presents sick at a health centre at least once per year.

Since 1993, the Masisi health district, which initially was among the best performing, has had to cope with ethnic conflicts and serious problems of insecurity, with an obvious impact on its performance.

Since the end of the eighties, CEMUBAC has invested annually approximately 7 million Belgian francs (US\$230,000) in the three health districts together. This amount covers 25 to 50 per cent of the expenses, the rest being provided by the inhabitants themselves. Thus, the rural health districts cost under US\$ 1 per inhabitant, per year. One episode of illness treated at a health centre in eastern Kivu costs about US\$1.5; referral to a doctor, US\$ 5; and hospitalization US\$ $25-50$.

\section{Participation in the Rwandan Emergency Relief Effort}

Hundreds of thousands of Rwandans crossed the border near Goma between 14 and 17 July 1994. They transformed the city and its neighbourhood into a huge refugee site. On $19 \mathrm{July}$, cholera, which is endemic in the area, broke out and quickly spread. The government of Zaire and the humanitarian agencies decided that the refugees had to leave the city. As a result, 800,000 refugees were concentrated in three camps: Kibumba, Mugunga and Katale. Cholera continued its devastation at these new sites. The epidemic waned, but multiresistant shigellosis immediately took over as a major killer (Goma Epidemiology Group 1995).

An estimated 120,000 to 250,000 refugees settled outside the camps and mixed with the local population. There are indications that they fared better, and in particular were less affected by cholera.

More than 18 months later, the refugees were still living in these huge camps. Mortality was lower than in July and August 1994, and possibly lower than that of their Zairrean neighbours outside the camps.

What was the role of the Zairean health services? We shall concentrate on those health centres where problems were most acute, and on the first four months following the refugee influx, when the health system was most in demand. 


\section{Rutshuru Health District}

The Rutshuru health district is located north of Goma, along the main road passing the camps of Kibumba and Katale. This health district was believed to be one of the main areas of settlement outside the camps. The number of refugees residing in the district, outside the camps, between July and October 1994 was estimated at $35,000-80,000$, compared with a local population of 214,000 inhabitants. These refugees had settled in 12 of the 14 health areas of the district, leading to an increase in population ranging from 1.9 to 70 per cent in the various health areas.

These refugees caused a spectacular rise in workload for the Zairrean health services. According to the health centre reports, the number of curative consultations, per month, for Zaireans, was approximately the same between July and September 1994 and during the first six months of the year. But the total number of curative consultations for the entire district increased by about 300 per cent, ranging from 0 per cent in the Vitshumbi health centre, located in the Virunga National Park north of Rutshuru, to about 750 per cent at the Rutshuru health centre.

Between 1 August and 30 September 1994, Rutshuru general hospital registered an increase of close to 140 per cent in the average monthly use of services.

In the health centres and the referral hospital of Rutshuru district, during the first 15 weeks following the influx, some 65,000 new cases were registered among refugees; it was estimated, in and outside the camps, that 100 new cases per 10,000 refugees presented themselves each day at a health centre; 65,000 new cases in 15 weeks thus correspond to a refugee population of 62,000 .

The weekly epidemiological reports showed that between 18 July and 21 August 1994, 19,707 patients (8,910 cases of diarrhoea, of which 4,111 cases of bloody diarrhoea, and 10,797 cases with other pathologies) were registered among the Rwandan refugees in the health centres and hospital of Rutshuru health district (Porignon et al. 1995). During the same period, 210 deaths among Rwandan refugees were reported in these health structures, probably a fraction of the total fatalities.

Refugees were treated completely free of charge in Rubare and Rutshuru health centres and Rutshuru hospital. Although refugees represented around one third of the population, they formed two thirds of the patients. The refugee utilization rate was five and ten times higher than that of Zaireans in Rubare and Rutshuru respectively. In Rutshuru, Zaireans' fear of infection from refugees kept them away. The increased workload obliged staff to concentrate on refugee patients. The laboratory was closed. In Umoja, on the other hand, where refugees had to pay for health care, few attended, better conditions were maintained in the health centre and Zairrean attendance increased.

The Rutshuru hospital was rapidly overwhelmed by refugees, the occupation rate being 150 per cent at the end of August, falling to 98 per cent by mid September. Hospitalizations of Zaireans were reduced by about 30 per cent 
(except in medicine, where indeed many Zaireans with cholera and shigellosis were admitted as well), due to fear of infection and deterioration in the quality of care.

The radiologist left the hospital to work for a humanitarian aid agency, taking with him all the departmental records.

The costs of treating the refugees were only retrieved some months later from UNHCR. The self-financing capacity of the health centres when refugees were treated free, was reduced four to five times. As a consequence, salaries, which are partly paid by the income of the health centre, had to be reduced by about 50 per cent although the workload increased considerably. Salaries paid by the humanitarian aid agencies were 2 to 10 times higher than salaries paid in the area! In such a context, it is surprising and comforting that very few defections-8 8 per cent-were observed among the personnel of the health centres.

Reduced self-financing capacity also affected the general hospital and the Bureau Central de Zone, which depends on income from the health centres for about 30 per cent of its expenses. Workload greatly increased, with insufficient logistical support-equipment, transport facilities, and fuel. Supplementary expenses of the office were partly reimbursed, later on, by UNHCR. An employee of the office on mission got US\$ 2 per day, an employee of any relief organization on mission received US\$25. As a consequence, 25 per cent of staff members left the office to join the humanitarian aid agencies between the end of 1993 and May 1995!

\section{Kirotshe Health District}

The Kirotshe health district, south of Goma, has 319,000 inhabitants. There is one general hospital. Among the 25 health centres, two larger ones have hospitalization facilities. Mugunga refugee camp is located in Goma health district, but very close to Kirotshe. The camp hosts 125,000 refugees, including many soldiers of the defeated Rwandan army. The number of refugees living outside the camp is estimated to be 38,000 .

Eight health centres had to cope with refugees. The two most in demand were Sake and Bulenga. The population in these areas, with 13,850 and 14,660 refugees, increased by 58 and 62 per cent, respectively. As far as the health centres are concerned, the same remarks apply for Kirotshe as for Rutshuru: increased workload, adequate response capacity with increased curative activities, but reduced income, self-financing capacity, and preventive medicine and health promotion activities.

Bulenga health centre is large, with maternity and hospitalization facilities. Sake is another large health centre, very close to the Mugunga camp. Refugees in the area represent 40 per cent of the population, but 75 per cent of the patients. Refugees were treated free; their utilization rate was three to five times higher than for the Zairreans, whose attendance fell.

Self-financing capacity in Kirotshe was reduced five times. 
Many staff defections were observed in Kirotshe health district. Difficulties arose because of the complete lack of coordination and collaboration between the humanitarian aid agencies active in the district area, and the local authorities, at all levels: health centre, health district, and local administration. As a consequence, life conditions-infrastructure and environment-of the local population markedly deteriorated after the refugee influx. Surprisingly, this did not cause too much antagonism, but there was certainly a loss of morale and sense of unfairness.

Unlike the Rutshuru situation, Kirotshe hospital did not suffer too much: numbers of refugees were reasonable. Refugees preferred to be hospitalized in Goma, easily accessible by road. As a consequence, utilization by the local population remained stable.

\section{Masisi Health District}

Problems were quite different in Masisi. The health district had 268,000 inhabitants in 1993: approximately 20 per cent native Zaïreans (Hunde), 5 per cent Tutsis, and 75 per cent Hutus. In 1994, significant population movements occurred inside the area; the population was reduced to approximately 200,000 inhabitants. As the majority of the population in 1994 was of Hutu origin, the area was extremely attractive for the incoming refugees. However, because of the longstanding conflicts between the native Hundes and the Rwandan immigrant population, the Zairean authorities decided that the 1994 refugees should not be allowed to enter the district. The number of refugees, in October 1994, was estimated to be only 12,000. There are no camps in the Masisi district.

Insecurity is the most important problem. Many employees of the health system left. Quite a number were Tutsis; threatened in Zaire, and attracted by the new regime in Kigali, many returned to Rwanda. Others joined the relief organizations. Seven out of the 23 operational health centres closed; three others no longer function effectively; only 13 are functional. Curative activity in the health centres is increasing; preventive medicine and health promotion activities are diminishing. As the people do not dare to travel, because of the insecurity, the occupation rate of the hospital dropped to 18 per cent in 1994.

The area received some support, characterized by inefficient coordination and collaboration, due probably to difficult access and lack of precise information. For instance, a humanitarian aid agency provided some help; however, the introduction by this organization of free medical care caused a lot of problems. UNHCR offered no support to the health centres, but on the contrary, offered support to the hospital, where no single refugee had been hospitalized!

\section{Response Capacity of the Zairean Health Services}

Thus the response capacity of the Zairean health services should not be overlooked. Although overwhelmed, the local hospitals and health centres 
made an undoubted contribution to the disaster response. Among the factors which played a role in the resilience of the rural health districts in the management of the disaster were the district-based organization of the local health system, the quality and the capacities of the trained medical and paramedical personnel and the administrators, the process of collegial decisionmaking, and the active collaboration offered by the staff members to the relief organizations.

These observations also suggest that the public health consequences of the $R$ wandan refugee crisis for the host population constitute an integral part of the disaster. Among these consequences, we should mention a decrease in the quality of care, because of the overload of work and the defection of many staff members and employees, a decrease or a breakdown in preventive activities, and a decrease in self-financing capacities which notably means wage cuts.

\section{The Humanitarian Aid Organizations' Contribution to the Local Health System}

The picture here is varied and generalization is not possible. In some circumstances, collaboration and coordination were quite satisfactory, in others not. It appeared clearly that contacts with organizations already active in north-eastern Kivu before July 1994, including MSF-Holland, UNHCR, the International Red Cross, Oxfam and Caritas, were much easier than with organizations without any experience of the area, or without any experience. Some, among the latter, apparently did not want to communicate at all.

The support offered by the humanitarian aid organizations consisted of 1) financial support, 2) drugs, medical equipment and logistic support, and 3) coordination.

Financial support at the height of the crisis was insufficient and did not cover the extra effort made at all levels of the local health services to respond to the disaster. This was extremely discouraging for the personnel, and ironic in view of the fact that the estimated cost to UNHCR of medical care per refugee during the 12 months following the influx was roughly 15 times as much as the per capita cost of local health services.

Drugs and medical equipment were provided in quantity, but frequently did not correspond to the requirements of the health districts. These supplies were standard packages designed for an emergency dispensary in a camp, rather than a health centre or an inpatient hospital with obstetric and surgical wards. Support here was thus quantitatively adequate, but qualitatively inadequate.

Logistic support-fuel for instance-was not provided, or in minimal amounts, to the health district. Support was provided at a later stage for the rehabilitation of buildings, latrines, etc. which had deteriorated with the huge numbers of refugees. 


\section{Effects of the Relief Intervention on Local Health Districts}

\section{Favourable}

Some humanitarian aid agencies have built up valuable expertise in dealing with large-scale emergencies. The health districts learned from the more experienced agencies such as UNHCR. There was some transfer of resources. The use of local manpower clearly entailed some transfer of knowledge. The whole area benefited from the very efficient communication network which was set up, although the health district never got direct access to it!

\section{Unfavourable}

Prices of consumer goods as well as wages increased sharply in the area. The free provision of health care for refugees-even outside the camps-seriously endangered the self-financing capacity of the local health services and caused frustration and discouragement among the Zaïrean population. The 'hijacking' of - frequently the most skilled - personnel working in the local health system, at all levels, further destabilized the already struggling health services. In addition to the diversion of personnel, some local relief agencies (e.g. orphanages) were diverted from their original local objectives, leaving Zaïrean at-risk groups unprovided for.

However, much more fundamental than the question of financial and material support, was the inadequate dialogue, coordination and collaboration between the humanitarian aid agencies and the local health services. The objectives and strategies of the aid agencies and the local health services sometimes diverged completely; intensive collaboration and coordination is required to avoid chaotic situations. Humanitarian aid was limited solely to refugees, implying refusal to recognize the distress of the Zaiirean population; this is painful for anybody who knows their precarious circumstances and the causes and mechanisms of the crisis in Central Africa. This led to discouragement and withdrawal of the local authorities, due also to the humanitarian aid agencies' disregard of them.

The lack of preparedness for the emergency clearly played an important role in the failure of coordination. More significant, however, were the different mindset, the different logic, and the different objectives and strategies of both systems. Despite the common aim of helping the victims, the primary objectives of the local health services and the humanitarian aid agencies differed widely. The rural health districts of eastern Kivu are looking for long-term integrated development, taking into account experience gained over the years, educating the population and staff members, stimulating self-reliance, slowly building up a coherent system aimed at becoming self-supporting, proactive and cost effective.

In contrast, humanitarian aid is not fundamentally concerned with causes and mechanisms, but requires 'marketable words and images' (Editorial 1995). Humanitarian aid is not concerned with future developments, once it can 


\section{8}

Philippe Goyens et al.

retire. It is remarkable that the local health system is cited only once (Van Damme 1995) in all the studies consulted on the Rwandan emergency.

\section{Proposals to Improve Collaboration between the Local Health System and the Humanitarian Aid Agencies}

The interaction between developmental and emergency aid organizations can be broken down into four stages: communication, coordination, collaboration and finally integration. The intensity of this interaction, in the end, determines the efficiency of the respective interventions. Lack of knowledge and of reciprocal consideration, slowness of communication, the difficulty of installing coordination between various actors are different aspects which need to be analysed. Global evaluation of the various activities, which is an absolute prerequisite for efficient crisis management, remains a very complex subject. This evaluation is clearly an integral part of the planning of any public health intervention, and is also necessary for fund-raising. The diversity of the objectives, the type of interventions, and the methodologies, very much complicate these procedures.

Another difficulty is the limited adaptability - both in quality and quantityof the health services. This adaptability is conditioned by the efficiency of the health system and its preparedness for the emergency. The latter is extremely difficult to develop because no funding is available for that type of activity. Procedures for funding and provision of logistic support to the health services are extremely slow; this is particularly the case when objectives need to be adapted and activities modified, even if these modifications are urgently dictated by changing local realities.

Furthermore, the conjunction of 'wild recruitment' of local personnel with the free health services provided by emergency aid greatly undermined the local health system, which frequently lost its most dynamic employees and faced the impossibility of further self-financing, precisely when its absorption capacity was strained to the utmost.

Finally, the handover from emergency to developmental aid organizations, when the crisis is stabilizing, remains a major problem. Preparation of the transfer of responsibilities is a long and dynamic process, requiring very close coordination.

The following proposals could be considered.

The risk of the development of emergency situations needs to be evaluated by the local health system as well as by the humanitarian aid agencies. Health information and monitoring systems, as well as early warning systems, need to be reinforced or implemented. The validity, sensitivity and specificity of these systems need to be evaluated.

A special team should be set up, perhaps under UNHCR auspices, including representatives of the local administration and health authority. Ideally, the coordinating team should meet before the disaster, making use of the information gathered by the local health system and its own knowledge of 
the intervention procedures in case of emergency. This team should guarantee that the fundamental principles of maximizing impact, consistency and fair play are respected. It should, for instance, be forbidden to hire employees of the local health system without previous agreement of the local health authorities; no distinction should be made between direct and secondary victims of the emergency.

The coordinating team should enable exchange of experience, expert advice and information, and contribute to improved coordination and integration of humanitarian aid and the local health services.

A reciprocal information system between humanitarian and developmental aid organizations, concerning their respective techniques of intervention, needs to be implemented. The capacity of the local health services needs to be reinforced, in order to give them more flexibility and to increase their adaptability in case of changing environment. The coordinating team should enable a better evaluation of the requirements of the health services, and allow resources, if necessary, for the acquisition of technical expertise, to train staff, build up reserves of relief supplies, and develop their logistic capacity.

The philosophy of the health services managed by the humanitarian aid agencies inside and outside the camps should be harmonized as soon as possible with the philosophy of the local health system, in order to integrate both in a coherent partnership.

The collection and circulation of health information, including gathering and analysis by the health services, as well as background information from the coordinating body, need to be improved; without background information, the quality of the collection of health information cannot be guaranteed.

Interventions, their pertinence and efficacy, need to be evaluated, and evaluation techniques scrutinized.

Finally, the coordinating team could also facilitate the transfer of responsibilities back from the humanitarian aid agencies to the local health services, once the emergency is stabilized.

COLAERT, J., GOYENS, Ph. and SCHYNS, Ch. (1978) 'Antigenic Variation of Vibrio EJ Tor during an Epidemic in Kivu'. Annales de la Saciélé Belge de Médecine Tropicale 58: 357-358.

DELACOLETTE, C., VAN DER STUYFT, P., MOLMA, K., DELACOLETTE-LEBRUN, C. and WERY, M. (1989) 'Etude de la mortalité globale et de la mortalité licé au paludisme dans le Kivu montagneux, Zaïre', Revue d'Epidémiologie et de Santé Publique 37: 161-166.

DELANGE, F. (1974) Endemic Goitre and Thyroid Function in Central Africa. Basel: S. Karger (Monographs in Paediatrics, volume 2).

DE MOL, P., BRASSEUR, D., HEMELHOF, W., TSHIMPAKA KALALA, BUTZLER, J.-P. and VIS, H. L. (1983) 'Enteropathogenic Agents in Children with Diarrhoea in Rural Zaire' Lancet i: $516-518$.

EDITORIAL (1995) 'Humanitarian Olympics: Solferino to Goma', Lancet 345: 529-530.

GOMA EPIDEMIOLOGY GROUP (1995) 'Public Health Impact of Rwandan Refuge Crisis: What happened in Goma, Zaire, in July, 19947 Lancet 345: 339-344.

GOYENS, Ph., GOLSTEIN, J., NSOMBOLA, B., VIS, H. L. and DUMONT, J. E. (1987) 'Selenium Deficiency as a Possible Factor in the Pathogenesis of Myxoedematous Endemic Cretinism', Acta Endocrinol. (Copenh) 114: 497-502.

IRS-CEMUBAC (1979) 'Symposium sur l'avenir de l'enfant dans le Kivu d'altitude', Bukavu. 
JONES, W. I. and EGLI, R. (1984) Farming Systems in Africa. The Great Lakes Highlands of Zaire, Rwanda, and Burundi. Washington: World Bank Technical Paper 27.

PORIGNON, D., NOTERMAN, J.-P., HENNART, Ph. et al. (1995) 'The Role of the Zairean Health Services in the Rwandan Refuge Crisis', Disasters 19: 356-360.

RIES, A.A., WELJS, J.G., OLIVOLA, D. et al. (1994) 'Epidemic Shigella dysenteriae type 1 in Burundi: Panrexistance and Implications for Prevention', J. Infect. Dis. 169: 1035-1041.

TONGLET, R, KATULANYA-ISU, CHIABRERA, F., DRAMAIX, M. and HENNART, Ph. (1991) 'Pattern of Attained Growth in 0 to 5 year-old Children from Kivu (Zaire)', Ecology of Food and Nutrition 26: 215-226.

VAN DAMME, W. (1995) 'Do Refugees belong in Camps? Experiences from Goms and Guinea', Lancet 346: 360-362.

VIS, H.L. (1968) 'General and Specific Metabolic Patterns of Marasmic Kwashiorkor in the Kivu Area', in MoCance, R.A. and Widdowson, E.M. (eds.), Calorie Deficiencies and Protein Deficiencies. London: Churchill Livingstone, pp. 119-134.

- (1975) 'Analyse de la situation nutritionelle dans la région des grands lacs d'Afrique Centrale. L'impasse démographique', Revue Tiers Monde XVI, 63: 567-594.

VIS, H. L., POURBAIX, Ph., THILLY, C. and VANDERBORGHT, H. (1969) 'Analyse de la situation nutritionelle de sociétés traditionelles de la région du lac Kivu: les Shi et les Havu. Enquête de consommation alimentaire', Annales de la Saciété Belge de Médecine Tropicale 49: 353-419.

VIS, H. L., YOURASSOWSKY, C. and VANDERBORGHT, H. (1975) 'A Nutritional Survey in the Republic of Rwanda', Ann. Mus. Roy. Afr. Centr. Sc. Hum. 87.

WIIS, W., CARAEL, M. and TONDEUR, G. (1986) 'Le Kivu montagneux. Surpopulation, sousnutrition, Erosion du sol (Etude prospective par simulations mathematiques)', Brussels, Académie Royale des Sciences d'Outre-Mer, Mémoires in $8^{\circ}$, Nouvelle Série, 21 (3).

WORLD BANK (1993) Better Health in Africa. Washington: World Bank Africa Technical Department, Human Resources and Poverty Division.

The authors thank the DG VIII of the European Commission and the 'Fondation Universitaire David et Alice Van Buuren' for active support. 